\title{
DE VERWOESTINGEN VAN BABYLON DOOR DARIUS I EN XERXES IN HET LICHT VAN BABYLONISCHE EN BIJBELSE BRONNEN.
}

In de lijst van tien bloeiende en machtige Oosterse steden, die in de beide eeuwen tussen ongeveer 730 en 530 veroverd en verwoest zijn, komt Babylon twee keer voor, in 689 en 648, en Jeruzalem ook twee keer, in 597 en 586. Is daarna met het optreden van Cyrus en de Perzen, door de tweede Jesaja zo geestdriftig begroet, werkelijk iets nieuws begonnen? Wie zou deze vraag ontkennend willen beantwoorden? En toch, bekijken wij de volgende halve eeuw: de veroveringen en verwoestingen gaan door: weer Babylon in 521 en in 482, weer Jeruzalem, waarschijnlijk in 485. Bekijken we even de politieke situatie na de verwoesting van Ninevé, na de ondergang van het Assyrische imperialisme. Ik heb elders uiteengezet dat, historisch gezien, de Chaldeeuwse dynastie, dus het NieuwBabylonische rijk, de rechtstreekse voortzetting en voltooiing is van het rijk der Sargonieden. De stichter der Chaldeeuwse dynastie, de vorst Nabopolassar, waarschijnlijk uit het geslacht van de oude Merodachbaladan, was beter diplomaat dan legeroverste. Hij liet de militaire acties in hoofdzaak over aan zijn bondgenoot, koning Kyaxares van Medië, maar ging daarna met het merendeel van de winst strijken. Bij de verdeling der invloedsferen wist hij het gehele Zuiden van het voormalige Assyrische rijk voor Babylonië te verkrijgen, dus ook geheel Syrië, Fenicië en Palestina, tot aan de Egyptische grens toe, terwijl de Medische aanspraken tot het Noorden en Oosten, met de oostelijke helft van Klein-Azië, beperkt zijn gebleven. Zijn zoon, de grote Nebukadnezar, erft van hem de taak, deze invloedsfeer in het Westen te bezetten en te veroveren en het door hem schitterend opgebouwde Babylon in de plaats van Ninevé tot de hoofdstad te maken van een rijk, dat zich tot Fenicië en de Delta heeft uitgestrekt. Over zijn oorlogen gedurende zijn eerste tien regeringsjaren weten wij thans meer door de KroniekWiseman in het Brits Museum, waar ook de eerste verovering van Jeruzalem in maart 597 vermeld is: over het lot van de in de ballingschap weggevoerde koning Jojachin en de zijnen verneem wij iets uit de teksten, die Ernst Weidner gepubliceerd heeft.

Van toen af was voor de profeten en psalmisten in Juda en in de ballingschap niet meer Assur of Nineve, maar Babylon de vijand, die met verwoesting werd bedreigd. Het is alles behalve gemakkelijk deze bedreigingen in hun historisch verband te rangschikken. Bij een profetie als Jes. 21: „Gevallen, gevallen is Babel en al haar afgodsbeelden heeft Hij ter aarde verbrijzeld"---zou men nog aan de eerste berichten kunnen denken, die Jeruzalem omtrent de verwoesting van Babylon door Sanherib in 689 hebben bereikt. Moeilijker is deze verklaring al bij Jes. 13 en 14, waar Babylon, de trotse luister der Chaldeeën, zou worden als Sodom en Gomorra en in eeuwigheid niet meer bewoond worden. Want in 689 waren niet de Meden de vijanden $(13,17)$ en wie zou de trotse koning 
van Babylon zijn, de uit de hemel gevallen morgenster, die volgens hoofdstuk 15 naar het dodenrijk afdaalt? Vrijwel onmogelijk is deze verklaring reeds in Jes. 47: „Daal af, zet $\mathrm{u}$ neer in het stof, jonkvrouw, dochter van Babel . . . zet $\mathrm{u}$ zwijgend neer, ga in de duisternis, gij dochter der Chaldeeën, want men zal u niet langer gebiedster der koninkrijken noemen..." Want een gebiedster der koninkrijken is Babylon ook onder de Chaldeeuwse koning Merodach-baladan nooit geweest. Het ligt voor de hand reeds hier aan het exiel te denken, dus evenals bij de hartstochtelijke voorspelling der verwoesting van Babylon in Jeremia 50 en 51, welke voorspelling trouwens opvallende punten van overeenkomst vertoont met Jes. 13 en Jes. 47. In zuiver literair opzicht-_,formgeschichtlich", zoals men in 't Duits zou zeggen-staan deze profetieën met elkaar door aanhalingen en zinspelingen in een duidelijk verband en men krijgt wel eens de indruk, dat oude profetieën en waarschuwingen tegen de Babylonisch gerichte politiek van koning Hizkia--dus uit de tijd van de eerste Jesaja en van koning Merodach-baladan-later telkens weer aangehaald, uitgebreid en op de situatie van eigen tijd toepasselijk gemaakt werden. Maar dan moeten zij ook toepasselijk zijn-en hier ligt vaak de moeilijkheid. Daarbij kwam nog dat men slechts met bedekte termen de onderdrukker kon bedreigen. Uitdrukkingen als šešak en lēb qāmai bij Jeremia worden toch nog steeds het best verklaard als geheime namen, kryptogrammen voor Babel en de Chaldeeën. De oude strijdvraag, of hetzelfde wellicht ook voor Gog en Magog bij Exechiël geldt, laat ik in het midden. Lang niet overal is de tijdsbepaling zo gemakkelijk als bij de zo duidelijk exielische psalm 137 met zijn voor de jongere psalmdichting typerend alternerend ritme (3.3.3.3.3 en geteld worden de alternerende syllaben. Het oudere ritme is geheel anders: bijna altijd 2.2.2.2 en geteld worden de accenten der woorden. Het onderzoek naar het ritme als een norm voor de tijdsbepaling is moeilijk, maar belangrijk). De wraakkreet aan het einde dezer psalm, waarin de verpletteraar van zuigelingen gelukkig wordt geprezen, vormt een wankklank aan het einde van dit aangrijpende lied van heimwee. Wellicht gaat het hier toch niet enkel om wraakzucht. De dichter heeft-zo mogen we veronderstellen-als kind de verwoesting van Jerusalem in 586 overleefd en sindsdien was zijn lot en leven dat van een balling in de vreemde. En nu juicht hij degene toe die aan Babylons kinderen hetzelfde droeve lot op de dag der vergelding door een vlugge dood bespaart. Maarook deze verklaring veronderstelt de verwoesting van Babylon. En koning Cyrus heeft Babylon immers niet verwoest. Hij is op 29 oktober van het jaar 539 (we weten de datum nauwkeurig) de ongerepte stad door het verraad der priesters en onder het gejuich der bevolking binnengetrokken. Zijn het slechts wensdromen geweest, vrome of minder vrome wensen, die onvervuld zijn gebleven?

Integendeel: zij werden vervuld. Onze fout is alleen, dat wij de geschiedenis van Babylon met het jaar 539 plegen af te sluiten. $\mathrm{Er}$ is in de 
onmiddellijk daarop volgende jaren meer gebeurd met Babylon en ook met Jeruzalem en daarover willen wij hier handelen.

Een soortgelijke moelijkheid geldt trouwens ook de vader der geschiedschrijving: Herodotus. Zijn beschrijving van Babylon en de tempels wijkt dermate af van alles wij door inscripties en opgravingen daarover weten, dat critici wilden ontkennen, dat hij wel ooit zelf in Babylon zou zijn geweest. Deze kritiek gaat te ver: hij is er wel degelijk geweest, maar het Babylon, dat hij omstreeks het jaar 465 bezocht, was niet meer hetzelfde, dat Nebukadnezar had gebouwd en dat Cyrus ongerept had gelaten. Het Qasr, het stadsdeel waar de Isjtarpoort lag en de verwoeste paleizen, was toen zelfs voor de Babyloniërs verboden terrein, dat slechts door de Perzische militaire bezetting mocht worden betreden. Het was door de gewijzigde waterloop van de Eufraat gescheiden van het tempelterrein, het tegenwoordige Amrān. De tempel Esagila lag verwoest, de tempeltoren Etemenanki was een ruine, waarvan de trappen en ook het tempeltje op de top ontbraken. Reeds Darius had de stad ontmanteld en zijn zoon Xerxes had enige jaren vóór zijn Griekse veldtocht de stad en de tempels-ook de beroemde tempeltoren-laten verwoesten. Wat Herodotus daar, ongeveer twintig jaar na deze verwoesting, moet hebben gezien, zijn-voorzover hij er dan dichtbij mocht komen-ruïnes geweest en zijn kleurrijke beschrijving van deze gebouwen berust op de herinneringen en op de verbeeldingskracht van zijn Griekse gasturienden en tolken.

Wat was gebeurd? W $\mathrm{ij}$ beginnen in chronologisch omgekeerde volgorde met de verwoesting door Xerxes. In 't voorjaar 1939 verwierf $\mathrm{ik}$ in Baghdad van de handelaar Samhiry naast vele andere stukken een groep van bijna 250 kleinere kleitabletten, die van dezelfde vindplaats af komstig zijn: Babylon. Niet minder dan 150 daarvan zijn afkomstig uit de 43 regeringsjaren van koning Nebukadnezar II: korte kwitanties, nauwkeurig gedateerd, die ik allen heb ontcijferd en gerangschikt. De gehele groep heeft thans de inventarisnummers $1516-1770$ in onze collectie in het Instituut voor het Nabijie Oosten te Leiden. De oorkonde, waar het hier om gaat, is No. 1718: die jongste in chronologische rangschikking. Wat dan nog volgt, tot 1770 , zijn oorkonden uit dezelfde groep, waarvan de datering of de koningsnaam afgebroken of onleesbaar zijn.

No. 1718 is geen pronkstuk, Twee fragmenten, waarvan de hoeken ontbreken, zijn aan elkaar gelijmd. Slechts de voorzijde is leesbaar, maar ook daar eigenlijk maar drie regels in hun geheel. Het is een koopcontract zoals er zo vele zijn en toch zijn de taalkundige moeilikheden groter dan bij soortgelijke oorkonden het geval pleegt te zijn. Op de achterzijde hebben de namen voor de getuigen gestaan. Het woord voor getuigen (amël mu-kin) kan men nog juist lezen en het eerste stuk van een naam, die met $\mathrm{d}_{\text {Nabu }}$ begon. De rest is zwart en verschroeid. Blijkbaar werd de houten plank, waarop het tablet heeft gelegen, door vuur aangetast. Hierbij is het merendeel van de achterzijde afgebrokkeld en met een laag van houtas bedekt. Gelukkig-en dat is inderdaad een 
geluk-zijn hiervan juist de laatste regels gespaard gebleven, daar waar het kleitablet al naar de rand toe gebogen is. En juist deze regels bevatten de datering met de koningsnaam. Jammer is weer-want hier komt het, zoals we zullen zien, op elke bijzonderheid aan-dat het ideogram van de maandnaam verminkt is. Hier is de lezing nauwelijks twijfelachtig. Het is de maand $\mathrm{Abu}, \mathrm{Ab}$, de vijfde maand van het Babylonische en ook van het Joodse jaar. Het onderschrift luidt: ${ }^{a r a h} A b u$ ûm $4^{k a ́ m}$ sag-nam-lugal (d.w.z. rêš šarrūti) I d šamaš-eriba šàr Bābili u mātāti „op de vierde dag van de maand Abu uit het accessie-jaar van Šamašeriba, de koning van Babylon en der landen".

Het accessie-jaar (letterlijk het ,,begin van het koningschap") omvat, zoals bekend is, de maanden vóór 1 Nisan, die nog met het laatste regeringsjaar van de voorganger samenvallen. Het eerste regeringsjaar begint dan met de plechtige troonsbestijging op het nieuwjaarsfeest, dat deze Samaš-eriba niet meer heeft beleefd. Zijn naam zal men ondanks zijn trotse titel, waarmee hij aanspraak maakt op geheel het Achaemeniedische rijk, in de lijsten der Babyloniscche, laat staan der Perzische, koningen vergeefs zoeken. Toch is hij reeds bekend sedert 1888, toen Strassmaier in de derde jaargang van het toen nog jonge Zeitschrift für Assyriologie de eerste oorkonde uit de regering van deze toen geheel onbekende koning in autographie en een slechte transcriptie publiceerde, terwijl hij een vertaling toen nog niet aandurfde. Sinsdien zijn er-de Leidse incluis-negen zulke oorkonden bekend geworden, en van de andere pretendent, Bêl-šimanni, drie, dus in 't geheel juist een dozijn. Met deze twaalf oorkonden en hun nauwkeurige tijdsbepaling willen wij ons hier bezig houden. Zij behoren, zoals we zullen zien, in de eerste jaren der regering van koning Xerxes. Die van Šamaš-eriba zijn gedateerd tussen $4 \mathrm{Ab}$ en 23 Tišri van diens accessie-jaar. Dit zou kunnen betekenen -verondersteld, dat het argumentum e silentio hier op zijn plaats isdat hij zich ongeveer een kwart jaar heeft gehandhaafd, want de maanden $\mathrm{Ab}$, Elul en Tišri volgen op elkaar. $\mathrm{Nu}$ is er nog een tweede usurpator geweest, een zekere Bêl-šimanni, die door dezelfde weidse titel eveneens aanspraak schijnt te hebben gemaakt op geheel het Achaemeniedische rijk, maar die blijkens de drie oorkonden, die van hem bekend zijn, vermoedelijk niet veel langer dan veertien dagen heeft geregeerd. Volgens de ,communis opinio"- -voor zover men reeds daarvan zou kunnen spreken-is hij de oudere van de twee geweest, die beiden als pretendenten onmiddellijk op elkaar zouden zijn gevolgd. Het eerste is juist, maar hun optreden valt, zoals ik meen te kunnen bewijzen, in twee verschillende jaren.

De titels, die zij pretenderen, gelden niet alleen Babylonië, maar het gehele rijk in zijn volle omvang. Om dit duidelijk te maken, geef $\mathrm{ik}$ eerst even een overzicht over deze titels, beginnende met de Chaldeeuwse dynastie, waarvan de koningen in de dateringen der contracten steeds enkel ,koning van Babylon" worden genoemd. Nebukadnezar II volstaat ook in zijn officiële inscripties met deze titel, terwijl zijn vader 
Nabopolassar hieraan gaarne nog het archaistische „koning van Sumer en Akkad" toevoegt en Nabunaid de eveneens archaïstische titels ,,koning der wereld en koning der vier wereldstreken". De echte Perzische koningstitel luidde: „koning der koningen, koning der landen”. In de babylonische contracten was het tot een bepaald tijdstip-n.l. in het vijfde jaar van Xerxes-steeds ,,koning van Babylon en der landen" of ook wel ,koning van Babylon, koning der landen", waarmee dus duidelik twee helften van het rijk bedoeld zijn. Varianten zijn hier slechts veroorzaakt door het corregentschap van Cambyses, toen deze „,koning van Babylon" was, înušu Kuraš abušu šar mātāti, d.w.z. terwijl zijn vader Cyrus koning was der landen. Een tweede variant is die van Xerxes, die in het eerste begin van zijn regering de titel ,koning der Meden en Perzen" bij wijze van uitbreiding aan de gewone titel deed voorafgaan: in dit geval, voorzover wij kunnen nagaan, zonder politieke betekenis, alleen om de Perzische suprematie te doen uitkomen.

„Koning van Babylon en der landen". Wat is daarmede bedoeld? Onwillekeurig denkt men aan een splitsing van het rijk in een westelijke en een oostelijke helft, zoals later b.v. West- en Oost-Rome: het Westen met Babylon en het Oosten met Pasargadae, Susa of Persepolis als hoofdstad, te vergelijken met Rome en Byzantium. Maar dan zou de westelijke helft, hoewel de ondergeschikte, bij een uitbreiding tot Klein-Azië en Egypte onevenredige omvang en betekenis hebben gehad. Deze verdeling moet veeleer historisch worden beschouwd: in een Zuidelijke en een noordelijke helft.

$\mathrm{Na}$ de ondergang van het Assyrische imperium hadden indertijd Nabopolassar en Kyaxares de wereld in twee invloedsferen verdeeld, een zuidelijke en een noordelijke, Tot de zuidelijke sfeer, met Babylon als hoofstad in de plaats van het verwoeste Nineve, behoorde Elam, dus de vlakte ten zuiden van het Iraanse hoogland, dan vooral Babylonië met het zuidelijkste gedeelte van het oude Assyrië, zuidelijk Syrië, ongeveer tot aan Euphraat en de Balich en waarschijnlijk langs de weg over Aleppo naar Latikije, bij het oude Ugarit, dus Phoenicie, en Palestina tot aan de Egyptische grens. Dat was het rijk van Nebukadnezar, dat deze-niet reeds zijn vader-vast in zijn bezit kreeg en dat onder de Achaemenieden tot het vijfde regeringsjaar van Xerxes intakt bleef. Tot de noordelijke sfeer echter behoorden de overige "landen", met het oude gebied der Ummanmanda als middelpunt: Perzië en Medië, het eigenlijke Assyrië met Urartu, Noord-Syrië van de Euphrat tot aan de bergen (hier was de streek van Harrān lang omstreden gebied) en Klein-Azië tot aan de Griekse steden, met Sardes als het middelpunt. Het was een toestand van politiek evenwicht, die aanvanklijk nog onder het Perzische eenheidsrijk bestaan bleef.

Maar in het vierde jaar van koning Xerxes moet iets gebeurd zijn, waardoor dit evenwicht werd verbroken. Opeens wordt Babylon geschrapt uit de koninklijke titulatuur en blijft alleen nog de titel ,,koning der landen" over. En van toen af blijft de titel enkel ,koning der landen” 
šar mātāti tot aan het eind van de Achaemeniedentijd. Pas de eerste Seleukieden hebben na de poging van Alexander om Babylon weer tot het middelpunt van zijn rijk te maken, de oude titel tijdelijk hersteld. Van Seleukos II (247-26) af heten zij in de babylonische contracten kort en bondig ,,de koning", terwijl de Arsacieden de oude Achaemenidische inheemse titel ,koning der koningen" hebben aanvaard.

Nu het probleem: wat is in het vierde jaar van Xerxes gebeurd, dat aanleiding heeft gegeven tot een zo radicale wijziging van de koninklijke titulatuur? Een oorkonde van 1 Elul (dus de vijfde maand) van het vierde jaar is nog gedateerd uit de regering van Xerxes, de koning van Babylon en der landen; de beide oorkonden uit het vijfde jaar, van 22 Nisan en 2 Tamuz, dus uit de eerste en vierde maand, dragen alleen nog de titel ,koning der landen". Wat is in de tussentijd in Babylon gebeurd, dat het zo radicaal werd verwijderd uit de titulatuur en vermoedelijk in werkelijkheid? Het waren, zoals ieder gymnasiast uit zijn Herodotus weet, veelbewogen jaren: na de nederwerping van de Egyptische opstand, midden onder de voorbereidingen tot de veldtocht tegen Hellas en wellicht ook, zoals uit de zogenaamde Daiva-inscriptie blijkt, van een religieuze hervorming, die door intolerante houding tegen de aanhangers der oude goden-volgens Xerxes afgoden-tegenstand moest opwekken. Niet alleen bij gebrek aan tijd, maar ook om methodische redenen beperk ik mij tot de primaire bronnen uit Babylon zelf, al zijn het slechts kwitanties en contracten, dus zonder te letten op de verhalen der Griekse schrijvers, die levendiger zijn, maar vaak anecdotisch en phantastisch. (De klassieke bronnen voor een verwoesting van de stad Babylon onder Xerxes, zijn, zoals bekend, Strabo XVI 1, 5 en Arrianus III 16 en VII 17, terwijl Herodotus in het derde boek zijn mooi verhaal van het muildier, dat een veulen werpt en van de verminking van Zopyros nog ten tijde van Darius plaatst. Ook de gegevens op grond van de opgravingen, zoals Wetzel die in zijn verhandeling over Babylon zur Zeit Herodots naar voren heeft gebracht, komen in aanmerking. Opzettelijk beperken we ons tot de babylonische bronnen.)

Het probleem luidt dan: wanneer hebben de opstanden der beide pretendenten Rêl-šimanni en Šamaš-erïba, die Xerxes niet alleen als šar Bābili, maar zelfs als šar mātāti wilden verdringen, plaats gehad? Wij moeten deze opstanden, zoals ook uit de datering der Leidse oorkonde blijkt, over twee verschillende jaren verdelen. De terminus a quo is toch in ieder geval de troonsbestijging van Xerxes. Blijkens de dateringen der babylonische contracten sterft Darius in November 486 en heeft Xerxes op 1 December van hetzelfde jaar reeds de troon beklommen. (Bij de omrekening in onze kalender en tijdrekening volg ik de tabellen van Parker en Dubberstein in hun onmisbaar boek over de Babylonian Chronology, en wel in de tweede druk van 1946 (SAOC No. 24).) De terminus ad quem is de wijziging van de koningstitulatuur, die in verband moet hebben gestaan met de nederwerping van de tweede langere en gevaarlijker van deze beide opstanden, dus die van Šamaš-eriba en met een-tenminste 
gedeeltelijke-verwoesting van de stad Babylon en de (ook door Herodotus) betuigde wegvoering van het standbeeld van Marduk uit de tempel van Esagila en een radicale wijziging van de structuur en de administratie der zuidelijke helft van het rijk. Want, zoals bekend is, werd Syrië van toen af een zelfstandige satrapie, terwijl Babylonië werd ingelijfd in de nieuwe satrapie van Assyrië.

Met het oog op deze belangrijke gebeurtenissen is het zeker de moeite waard, het dozijn babylonische oorkonden, dat naar deze beide pretendenten gedateerd is, wat nader te bekijken, en wel vooral met het oog op een nauwkeuriger tijdsbepaling. Eerst nog een algemene opmerking: Overlapping van konigsnamen bij zulke dateringen uit dezelfde stad of streek mag men niet veronderstellen. Zij droegen immers een officieel karakter en werden door een administratieve maatregel voorgeschreven: een der allereerste maatregelen van een nieuwe koning of pretendent na de aanvaarding van de regering. Op de zelfs voor het hedendaagse volkenrecht lastige vraag, op welk tijdstip een revolutionaire usurpatie wettig wordt, was het antwoord toen niet twijfelachtig: zodra de pretendent over het leger en de ambtelijke organen beschikt. En dat was bij onze pretendenten blijkbaar het geval, hoewel vanzelfsprekend niet in geheel het wereldrijk, maar dan toch tenminste in de omstreken der hoofdstad Babylon tot Borsippa en de twaalf $\mathrm{km}$ ten $\mathrm{Z}$. daarvan gelegen stad Dilbat toe. Daar kon ook een legitimistich Perzisch gezinde firma haar kwitanties en registers dan niet meer naar het regeringsjaar van de wettige koning dateren: zij zouden ongeldig geweest zijn. Tot Persepolis natuurlijk heeft zich deze beweging nooit uitgestrekt. In de grote editie der Persepolis Treasury Tablets (door Cameron) behoeft men de namen van deze pretendenten ondanks hun weidse titulatuur niet te zoeken. Doet men het toch, dan zal men opmerken, dat zelfs daar-waar de schatkist van het rijk was-kwitanties juist uit het vijfde regeringsjaar van Xerxes ontbreken. In Babylon ontbreken zij van zijn vijfde tot en met zijn 15de regeringsjaar geheel, met één enkele uitzondering in het 9 de.

$W_{i j}$ beginnen met de drie oorkonden uit het accessiejaar van Bêlšimanni en wij rangschikken alle twaalf hier te bespreken oorkonden chronologisch, waarbij de tijdsruimte, die zij beslaan niet groot is: in het eerste geval veertien dagen, in het tweede een kwartaal min tien dagen. Van de eerste oorkonde kennen wij alleen de datering: „Te Borsippa, op de $15 \mathrm{de}$ (dit cijfer was, naar het schijnt, onduidelijk) van de maand $\mathrm{Ab}$ (dus de vijfde maand) uit het accessie-jaar van ,,Eêl-šimanni, de koning van Babylon en van de landen." Dit kleitablet behoorde indertijd tot de particuliere collectie van de Lord Amherst of Hakney en zal na diens overlijden wel het lot hebben gedeeld van al zulke collecties, die niet in openbaar bezit komen: naar alle windrichtingen te worden verspreid. Wijlen Pinches heeft op een congres te Hamburg in 1902 alleen dit onderschrift meegedeeld. Hij beschouwde de naam als Perzisch, hoewel reeds hij deze naam, die „o Bêl, verhoor mij” betekent, eigenlijk best had kunnen vertalen. Bij dezelfde gelegenheid verrijkte hij onze kennis ook 
nog met de naam van een ander onbekende Perzische koning, die hij Sikušti of dergelijke meende te moeten lezen; ' $k$ hoop slechts, dat het nageslacht later niet met zulke ironie over onze gissingen zal spreken. Zelfs nog Pallis in zijn overzicht over de jongste geschiedenis van Babylon tot aan de Romeinse tijd (verschenen te Kopenhagen in een bundel ter ere van Pedersen) droomt nog van een derde pretendent van die naam, terwijl toch reeds Cameron in 1941 (AJSL) de juiste lezing had aangetoond. Als men het goed leest, n.l. Ah-ši-i-war-ši, dan is het niets anders dan een der vele spellingen van de naam van koning Xerxes. Wij kunnen dus met twee pretendenten ten tijde van Xerxes volstaan.

De andere beide oorkonden uit het accessie-jaar van Bêl-šimanni zijn in het Museum te Berlijn, waar juist de kleitabletten in het souterrain ondanks alle verwoestingen vrij goed bewaard zijn gebleven. Het zijn de nummers 683 en 464. Als ik van nu af in verband met Berlijn nummers aanhaal, bedoel ik de bewerking in de Neubabylonische Rechts- und Verualtungsurkunden van San Nicoló en Ungnad. No. 683 is van 1 Elul van het accessie-jaar. En direct hier krijgen we een chronologisch houvast. De oorkonde is opgemaakt te Dilbat, $12 \mathrm{~km}$ ten $Z$. van Borsippa. Zover heeft zich dus de autoriteit van de usurpator uitgestrekt. Aan het heiligdom van de stadsgod Uraš, E-imbi-Anu, waren toen twee schrijvers verbonden, blijkbaar concurrenten. Nu wil de één-hij heet Murašū, van de ander diens ambt of bedrijf aflossen of afkopen. In tegenwoordigheid van de administrateur (šatammu) en van de gemachtigde (kîpu) van de tempel zegt hij tot zijn collega: minā dullu tupšarrūtuul teppuš ,gij zult geen schrijverswerkzaamheden meer verrichten". En deze stemt toe, afgezien van enkele speciale opdrachten, die hij nog moet afwerken. Deze verrekening nu heeft terugwerkende kracht en betreft het juist afgelopen halfjaar. Dit is de periode van het eind van de maand $\mathrm{Ab}$-dus één dag voordat de oorkonde werd opgemaakt-terug tot en met de maand Adar, dus de laatste maand van het voorafgaande jaar. De eerstegenoemde datum valt volgens onze oorkonde in het accessie-jaar van Bêl-šimanni. Deze moet dus na de maand Nisan (want anders zou het als zijn eerste regeringsjaar moeten worden geteld) en nog vóór Elul voor zich de troon hebben bemachtigd. Onze tekst luidt bij de bepaling van deze halfjarige periode in het verleden: ,, . . . vanaf de maand Adar van het eerste jaar tot aan het eind van de maand $\mathrm{Ab}$ ". Nu kan met dit eerste jaar, dat dus onmiddellijk aan het lopende jaar voorafgaat, onmogelijk iets anders bedoeld zijn dan het eerste regeringsjaar van koning Xerxes. Dus moet de opstand van Bêl-šimanni vallen in het tweede regeringsjaar van koning Xerxes, en wel in de zomer van het jaar $484 \mathrm{v}$. Chr. Dat de beide schrijvers en ook de in onze oorkonde vermelde administrateur van de tempel ook uit oorkonden uit de laatste jaren van koning Darius I bekend zijn, vermeld ik slechts terloops.

Want er is meer. Dit tweede regeringsjaar van koning Xerxes is geweest een schrikkeljaar, en wel een schrikkeljaar van bijzondere aard: niet de twaalfde, maar de zesde maand werd in dit jaar verdubbeld, m.a.w. 
dit jaar 484 had twee maanden Elul. Met zekerheid weten we dit pas door de Persepolis Treasury Tablets, waar No. 10 en 11 uit deze tweede maand Elul (in 't Perzisch de tweede maand Karbashiya) gedateerd zijn. $\mathrm{Nu}$ hebben wij uit ditzelfde tweede regeringsjaar ook oorkonden uit Babylon en Borsippa, die naar de naam van Xerxes zelf gedateerd zijn. Deze oorkonden zijn uit de maand Nisan, voorts van 14 en 15 Sivan, van 6 Tamuz (dat is de 22ste Juni)... en dan weer van de 25ste van de tweede maand Elul (dat is van 13 October). Tussen 22 Junie en 13 October is er een lacune. Naar onze stelregel, dat „overlapping” bij deze dateringen is uitgesloten, moet de korte revolutie van Bêl-šimanni dus hebben plaatsgehad tussen deze beide data. Op 22 Juni 484 werden de oorkonden nog en op 13 October weer naar koning Xerxes gedateerd. Daartussen liggende data van de beide tot nog toe besproken oorkonden zijn blijkens de omrekeningstabelle van Parker en Dubberstein gedateerd van 5 Augustus en van 21 Augustus van dit jaar 484.

$\mathrm{Nu}$ komt men hier nog weer een stap verder met behulp van de derde oorkonde uit het accessie-jaar van Bêl-šimanni. Het is een van de vele promessen, waarin zich de pachter van een met dadelpalmen beplant stuk grond verplicht bij de oogst aan de eigenaar een bepaalde hoeveelheid dadels te leveren. Deze hoeveelheid hangt af van de opbrengst en hoe gunstig of ongunstig deze zal zijn, kan men pas in de warme maanden $\mathrm{Ab}$ en Elul beoordelen. Dus zijn de meeste van deze oorkonden uit de maanden $\mathrm{Ab}$ of Elul. Dat zal ook hier het geval zijn, al zijn de opgaven betreffende maand en dag niet bewaard gebleven.

Dus: Bêl-šimanni is als pretendent een ephemere figuur. Hij heeft zijn kans waargenomen in de heetste dagen van de zomer van het jaar 484, toen de koning de handen vol had met de consolidatie van zijn rijk, vooral aan de Egyptische grens. Hij treedt op onder zijn eigen naam, wij weten niets over zijn familie en afstamming en op grond waarvan hij aanspraak meende te mogen maken op de troon van beide helften van het rijk. Zodra het eind September wat koeler wordt, vermannen zich de Perzen en de pretendent verdwijnt, even vlug als hij opgedoken was. Het leven, ook het handelsbedrijf gaat ongestoord door, alleen dat de oorkonden weer naar de wettige koning gedateerd worden.

Zeer veel ernstiger in zijn gevolgen en ook langer van duur is twee jaar later de opstand van de tweede pretendent geweest: Samaš-eriba. Laten we de negen oorkonden, die ik uit zijn regering ken, ook even bekijken. De oudste is onze Leidse, die ik al beschreef: No. 1718. Hij is in het vuur geweest, misschien toen Xerxes Babylon verwoestte, zijn leesbaarheid is daar niet beter op geworden. Bovendien is hij onduidelijk geschreven. Ten slotte kwam ik er achter, waar het om gaat: verkoop van een bitu šal-lap-pi-tum. Dat is geen akkadisch woord, maar niet onbekend. Het is een gebouw met vaste lemen wanden. De analoge sumerische uitdrukking is $\mathrm{i} m-z \mathrm{i}-\mathrm{kalag}-\mathrm{ga}$. Zulk een gebouwtje dus wordt 
verkocht, met de gebruikelijke opgaaf van de belendende percelen links en rechts. De koper heet La-qip, de zoon van Sin-kišir, de koopprijs bedraagt $\frac{1}{3}$ mina zilver en $4 \frac{1}{2}$ sikkel in stukken, die met $\frac{1}{8}$ gelegeerd zijn. Op de achterzijde stonden de namen der getuigen en het onderschrift. Dit is alles normaal. De oorkonde is, omgerekend en toegepast op het jaar 482, van 2 Augustus 482, dus weer in de zomer.

De tweede oorkonde, in Berlijn, No. 462 in de bewerking van San Nicolo en Ungnad, betreft weer de pacht van een palmentuin met de verplichting van levering van een gedeelte van de dadeloogst aan de eigenaar. De oorkonde is van 25 Elul van het accessie-jaar, dus van 22 September. Laat ik even zeggen, dat ook dit jaar 482 een schrikkeljaar geweest is, evenwel met een tweede Adar, dus pas in Maart van het volgende jaar, wat ons geen last veroorzaakt, want zolang heeft ook Šamaš-eriba niet geregeerd.

De derde oorkonde, in Berlijn, No. 463, behandelt weer hetzelfde. Alleen de hoeveelheden dadels, die bij de oogst in de maand Marcheswan geleverd moeten worden, zijn telkens verschillend. De oorkonde is weer uit de maand Elul, de dag is afgebroken. Dus Augustus 482.

De vierde oorkonde, in Berlijn, No. 464 van het vermelde werk, bevat met bepaalde variaties, hetzelfde: Verplichting tot de levering van een gedeelte van de dadeloogst als pachtprijs voor een palmhof in Borsippa. De opgaaf van de maand en de dag zijn niet bewaard gebleven. Natuurlijk betreft ook deze oorkonde de oogst in de maand Marcheswan en zal hij geschreven zijn in de maand Elul, dus eveneens in Augustus 482.

Vijfde oorkonde, Berlijn No. 90 (NBRV): Verkoop van een slaaf. Talrijke getuigen. Geschreven te Borsippa, evenals ook de vorige. Datum 21 Tišri van het accessie-jaar. Omgerekend: 18 October 482. Toen heeft Šamaš-erïba nog geregeerd. Reeds daarom kan zijn regering niet in hetzelfde jaar vallen als die van Bêl-šimanni. De volgende oorkonden zijn zelfs van nog latere datum in dezelfde maand. Evenals op de tweede noemt zich Šamaš-eriba ook op deze vierde oorkonde alleen ,koning van Babylon".

Zesde oorkonde, in het Brits Museum te Londen, collectie Spartoli II 19 , in autographie en in een onvolmaakte transcriptie reeds bekend sedert 1888. Gedateerd te Babylon één dag later dan de vorige oorkonde: op 22 Tišri, dus 19 October 482 . Het betreft de huur van een bitu husu, d.w.z. een met riet bedekte of ombeinde schuur. Nauwkeurig opgegeven worden weer de belendende percelen. De buurvrouw rechts is een nakomelinge van het bekende geslacht Egibi, het grote bankiershuis. De verhuurder heet Nidinti-Bêl, de huurder Nabû-balāt-ereš. Deze moet dagelijks een kleine hoeveelheid graan als huurprijs afstaan en bovendien als toegift in bepaaide maanden een honingkoek (nuptum). Uitdrukkelijk wordt bepaald, dat hij deze leveringen niet mag onderbreken: bațlu ul iššakan. Taalkundig levert deze interessant oorkonde verder geen moeilijkheden op. 
Zevende oorkonde, in Berlijn, No. 615 van het vermelde werk. Uit Borsippa, weer een dag later: 23 Tišri, dus 20 October 482. De oorkonde is in godsdiensthistorisch opzicht bijzonder interessant. Bêl-iddina, de zoon van Nabû-ahu-ittanu verplicht zich tot de geregelde levering van bepaalde porties meel, en wel voor de sacrale maaltijd (naptānu) van de god Nebo, dus in de Ezida-tempel te Borsippa. Zulke oorkonden zijn er meer: niet minder dan 37 daarvan worden aangetroffen in de Neubabylonische Rechts- und Verwaltungsurkunden, met een toelichting op blz. 494 v.: „Verpachtung von Tempelpfründen”. De provenier, die dus het recht heeft op een bepaald inkomen van de tempel, op voorwaarde, dat hij daarvoor de geregelde offermaaltijden moet annichten, draagt dit recht met deze verplichtingen aan een ander over. Vermoedelijk waren deze prebenden erfelijk, maar de rechthebbende kon niet altijd ter plaatse bij het heiligdom aanwezig zijn en moest dus daar iemand hebhen, die de sacrale handelingen voor hem verrichtte. De bijzonderheden over deze offermaaltijden (in Assyrië heten zij tākultu) zouden eens in iets ruimer verband (n.l. ook in Babylonië) onderzocht moeten worden. Voor ons hier komt het aan op de tijdsbepaling. Het eerste stuk van het verdrag wordt blijkbaar afgesloten voor een half jaar, het tweede voor een heel jaar. Het halve jaar wordt gerekend van de maand Marcheswan van het accessie-jaar van Šamaš-eriba, de koning van Babylon en der landen tot aan zijn uittocht (adi șitišu). Dat betekent: „tot aan het nieuwjaarsfeest in Nisan", waarop de officiële kroning moest plaatshebben. Op 5 en 11 Nisan werd Akitu ook in het parak šimăte te Borsippa gevierd, waar het standbeeld van Nebo toen vertoefde, terwijl de koning in eigen persoon uittrok, om het naar Babylon te halen. Wij moeten het halve jaar dus rekenen van begin Marchešwan tot begin Nisan. Hieruit volgt, dat ook dit jaar een schrikkeljaar is geweest, met twee maanden Adar. Een tweede Adar of Veadar (in 't Perzisch de tweede maand Viyahna) wordt volgens de dateringen der Treasury-Tablets behalve in het vierde pas weer in het twaalfde jaar van Xerxes aangetroffen, en dat zou te laat zijn. Onze tijdsbepaling: 4 de jaar $=482$ is dus juist. Het Akitu-feest in Nisan, dus in Maart 481, heeft deze pretendent niet meer beleefd en dus ook niet zijn eigenlijke kroning.

Achtste oorkonde, weer in Berlijn, No. 785 (NBRV), eveneens uit Borsippa, betreft een soortgelijk sacraal onderwerp. Het is een lijst van degenen, die dagelijks verplicht zijn meel te leveren 's ochtends en 's avonds voor de beide maaltijden van de god Nebo (wij zouden zeggen voor de spijsoffers) bij de tempel van Ezida. Deze verplichtingen gaan in op 29 Tišri van het accessie-jaar van Šamaš-eriba, dus feitelijk op de dag voor 1 Marcheswan en duren (zo kunnen we in gedachten aanvullen) even lang als bij de vorige oorkonde: zes maanden, tot de laatste dag van de maand Veadar. Is deze aanvulling juist, dan wordt onze tijdsbepaling ook hierdoor bevestigd.

Negende oorkonde, in Berlijn, No. 786 (NBRV): een soortgelijke oorkonde, al is hier het sacrale doel onzeker. Geleverd moeten in de 
eerste plaats worden grote hoeveelheden van makkasu, d.w.z. confitures, een soort dadelmarmelade, en wel in het accessie jaar van onze Samašeriba. Datum onleesbaar.

Dit zijn de twaalf oorkonden. Wij vatten ons resultaat samen: De beide pretendenten ten tijde van Xerxes zijn niet in hetzelfde jaar opgetreden. Tussen hun revoluties ligt een afstand van twee jaar. Eén ding hebben zij gemeen: zij maken hun revoluties in de heetste tijd van het jaar. (Persoonlik ken ik de babylonische zomerhitte slechts uit verhalen. Het moet nog veel erger zijn dan in Egypte.) $\mathrm{Nu}$ zal van een Perzische militaire bezetting in Babylonië toen nauwlijks meer sprake geweest zijn, vooral in 482 niet, toen Xerxes al zijn troepen tegen Hellas begon te mobiliseren. De weinige Perzische troepen, die er waren, zijn stellig niet zo geacclimatiseerd geweest, dat zij onmiddellijk effectieve tegenstand hadden kunnen bieden. Desondanks stort de eerste revolutie, die van 484, spoedig ineen en Xerxes behandelt de stad-het is immers de tweede hoofdstad van zijn rijk - nog met mildheid. Twee jaar later is de situatie ernstiger. In de zomer 482 kan hij geen revolutionaire bewegingen in zijn rug meer dulden. Hijzelf staat immers op het punt naar Sardes te vertrekken en vandaar verder over de Hellespont. Wellicht werden zijn plannen door de revolutie in Babylon ernstig vertraagd. $W_{i j}$ kennen immers de feiten: in de winter van 481 op 480 vertoeft Xeres in Sardes en op 23 September 480 is de slag bij S a l a m i s. De datum ontleen ik aan de Cambridge Ancient History: een der grote data in de geschiedenis der oudheid. Niet veel minder belangrijk, hoewel minder bekend, is echter hetgeen juist twee jaar eerder in Babylon gebeurde. Waarop Šamaš-etiba en zijn minder belangrijke voorloper met hun aanspraken eigenlijk steunden, weten wij niet. In ieder geval zijn ze onder hun eigen naam opgetreden, in treffende tegenstelling met de beide Pseudo-Smerdis en de beide Pseudo-Nebukadnezar's ten tijde van koning Cambyses en Darius I.

Tot het najaar, toen het weer koeler werd, heeft Šamaš-eriba zich kunnen handhaven: bijna een kwartjaar lang. Dat Babylon toen verwoest werd, lijkt niet twijfelachtig, ook afgezien van de klassieke verhalen bij Strabo en Arrianus. Deze verwoesting nu had een bijzonder doel en karakter. Niet de woonbuurten werden in de eerste plaats daardoor getroffen, maar de vestingwerken en vooral het centrale heiligdom. De stad werd nu volledig ontmanteld, de tempel Esagila en de tempeltoren Etemenanki werden ontwijd en gedeeltelijk afgebroken en het Mardukbeeld weggehaald. Dit laatste bericht zelfs Herodotus. Voorts wordt, zoals Wetzel aantoonde, de rivier afgeleid tussen de burcht en de verwoeste heiligdommen door, dus tussen de tegenwoordige heuvels Qasr en Amrân. Toen Herodotus een kleine 25 jaar later Babylon bezocht-welk feit wij met Wetzel niet in twijfel trekken-droegen de stad en de tempel nog menige sporen van deze verwoesting en moest hij genoegen nemen met overdreven verhalen over de vroegere pracht. Maar hierover heb ik elders gehandeld. 
Belangrijker in dit verband is een aandere vraag: was de Marduktempel in Babylon de enige, die toen verwoest werd? Hadden de beide pretendenten met hun trotse titels medeplichtigen in de provincies van het Westen, die immers toen nog tot de satrapie van Babylon behoorden? Hiervoor zouden de belangrijkste bronnen in het Oude Testament moeten worden gezocht en juist hier moet men voorzichtig zijn, daar de halve eeuw tussen de begintijd van Darius I en die van Artaxerxes I -laten we zeggen van 510 tot 460 --een donkere periode is in de geschiedenis van Judea, waarin men alle mogelijke gegevens kan rangschikken, maar zonder duidelijk bewijs.

En nu denk ik aan de breedvoerige en scherpzinnige stellingen van Julian Morgenstern in de Jaarboeken van het Hebrew Union College in Cincinnati (HUCA) sedert 1951. Morgenstern denkt aan een verwoesting van Jeruzalem en ook van de tweede, pas door Zerubbabel herbouwde, tempel door Xerxes reeds in diens eerste regeringsjaar 485 en verzamelt hiervoor ontelbare bewijsplaatsen en gegevens uit het Oude Testament. Natuurlijk dreigt bij een zodanig onderzoek steeds het gevaar van de circulus vitiosus: men verzameit vermeende bewijsplaatsen voor een hypothetische gebeurtenis en men staaft daarna deze gebeurtenis met behulp van deze bijbelplaatsen. Maar er is meer. De opstand van Samaš-eribu in Babylon heeft, zoals wij gezien hebben, pas in 482 plaatsgevonden, en voor een verwoesting van Jeruzalem nog vóór de veldtocht tegen Hellas is daarna geen tijd meer. Zouden de Joden, die zo hartstochtelijk de ondergang van Babylon hadden gewenst en die alles aan de Perzen te danken hadden, nu opeens hebben samengespannen met Babylonische pretendenten? Inderdaad denkt Morgenstern bij zijn constructie dan ook niet aan de gebeurtenissen in Babylon, maar aan die in Egypte. In Egypte zijn nog in het laatste jaar van koning Darius, dus in 486, onlusten uitgebroken. In November van dit jaar 486 sterft Darius en beklimt Xerxes, die al sedert 498 vice-koning in Babylon was geweest, de troon van het wereldrijk. Zijn eerste taak was een eind te maken aan de Egyptische opstand. Dat de revolte ook in Jeruzalem onlusten ten gevolge heeft gehad, kunnen we wellicht besluiten uit de aanklacht, die toen blijkens Ezra 4:6 bij het Perzische hof werd ingediend. Dat Xerxes persoonlijk over Palestina naar Egypte getrokken is en dat de opstand reeds in januari 484 gedempt werd, is zeker. Dat Xerxes echter bij die gelegenheid-dus inderdaad in 485-Jerusalem met de onaanzienlijke tweede tempel weer zou hebben verwoest-dus de tweede verwoesting sedert 586 -is toch wel een hypothese, waarvoor men graag duidelijker gegevens buiten het Oude Testament om zou willen hebben. Laten wij, in plaats van hierop in te gaan, liever naar Babylon terugkeren, maar nu veertig jaar eerder dan het jaar 482: de beide pseudoNebukadnezars, die zich in Babylon tot koningen hebben opgeworpen onmiddellijk vóór de troonsbeklimming van koning Darius I, de eerste van oktober tot december 522 , de tweede van eind augustus tot eind november van het jaar $521 \mathrm{v}$. Chr. Hier is de situatie aan de éne kant 
gunstiger, aan de andere kant ongunstiger dan in het geval der beide pretendenten onder Xerxes. Gunstiger, omdat wij hier de Behistuninscriptie hebben: een primaire bron van de eerste rang, het grote raam waarin de schaarse Babylonische gegevens, voor zover die er dan zijn, gerangschikt kunnen worden.

Behistun $\S 16,18$ en 19 bericht koning Darius over de opstand en de val van de Babylonische usurpator Nidintu-Bēl, de zoon van Aniri, die verklaart: „Ik ben Nebukadnezer, de zoon van Nabunaid."

Behistun $\S 49$ en 50 lezen wij over de Armeniēr Araka, de zoon van Chaldita, die letterlijk hetzelfde verklaart. De overwinning wordt in beide gevallen beschreven met opgaaf van de plaats waar de beslissende veldslag werd gestreden en met nauwkeurige datering: Nidintu-Bêl werd verslagen op 13 december en gedood op 18 december 522; Araka wordt gevangen genomen en gedood op 27 november 521. Zulke uitvoerige en nauwkeurige gegevens hebben wij bij Bēl-šimanni en Šamašeriba niet. Dit is dus gunstiger.

Veel ongunstiger is echter, dat zij niet onder hun eigen naam zijn opgetreden. Beiden regeren slechts kort: de een $2 \frac{1}{2}$, de ander ruim drie maanden, beiden in het najaar. Geen van beiden heeft dus het nieuwjaarsfeest, omstreeks ons Pasen, maart-april-beleefd. Dit weten wij hierom met volkomen zekerheid, omdat wij van maart-april 522 nog oorkonden hebben, die gedateerd zijn naar Cambyses en naar Bardija (dus pseudo-Smerdis) en van maart-april van het volgende jaar reeds oorkonden gedateerd naar koning Darius. Desondanks zijn al de tien oorkonden, die wij met enige zekerheid aan Nebukadnezar III kunnen toeschrijven, gedateerd uit diens accessiejaar, en alle 26 oorkonden van Nebukadnezar IV uit diens eerste regeringsjaar. Hieruit zou men kunnen besluiten, dat Nebukadnezar IV niet alleen onder dezelfde naam is opgetreden, maar zijn regering eenvoudig als de voortzetting beschouwde van die van de oudere pretendent, wiens dood hij negeerde. Hij is dus als het ware een pseudo-Nebukadnezar in de tweede macht. Dit is ook hierom zo eigenaardig, omdat bijna gelijktijdig ook twee pseudo-Smerdissen zijn opgetreden: eerste de zogenaamde magiër Gautăma en daarna Wahjazdăta van de stad Tảrowa. Hier was er alleen dit verschil, dat die twee elkaar bestreden, totdat Darius als de tertius gaudens met de buit ging strijken. Het is dus een ingewikkelde geschiedenis: zowel bij de oorkonden gedateerd naar Bardija, d.i. Smerdis, alsook hij de oorkonden gedateerd naar Nebukadnezar moet men zich steeds afvragen, welke van de verschillende pretendenten bedoeld is. En bij Nebukadnezar komt natuurlijk altijd vooral en in de eerste plaats de echte grote Nebukadnezar in aanmerking, de tweede van die naam. Het eerste probleem betreft dus ook hier weer de chronologische rangschikking der Babylonische oorkonden naar hun dateringen. Deze rangschikking is bij de pretendenten onder Xerxes gelukt: omdat wij hun namen hadden. Dat is bij Nidintu-Bēl en bij Araka moeilijk, vaak bijna onmogelijk: omdat $z i j$ onder het mom van een beroemde voorganger zijn opgetreden. 
Het eerste probleem luidt dus: Hoe onderscheidt men oorkonden uit het accessie-jaar en het eerste regeringsjaar van de grote Nebukadnezar van die uit de regering van deze beide pretendenten? Die twee van elkaar te onderscheiden is dan minder moeilijk, daar dan alle accessiejaren van Tišri tot Kislev aan Nidintu-Bēl (of Nebukadnezar III) en alle eerste jaren van de maand $A b$ tot Tišri aan Araka (of Nebukadnezar IV) moeten worden toegeschreven. Maar de grote Nebukadnezar zelf heeft toch natuurlijk in de jaren 605 en 604 nog veel meer oorkonden gehad, die naar $z i j n$ accessie en $z i j n$ eerste regeringsjaar werden gedateerd.

Het zou gemakkelijk zijn, als de titulatuur ons kon helpen: dus als de grote Nebukadnezar II zich alleen ,koning van Babylon” noemde, de beide pretendenten echter zich ,"koning van Babylon en der landen” noemden. Zover gaat echter de pretentie slechts bij Nebukadnezar IV in een zeer bepaalde groep van oorkonden. Dus blijft alleen de norm der persoonsnamen over, vooral bij de getuigen, waar telkens ook de naam van de vader en vaak die van de grootvader vermeld is. Dan is de identiteit der personen niet twijfelachtig. Vinden wij b.v. dezelfde persoon als getuige in oorkonden uit de tijd van Kambyses of van Darius I en van Nebukadnezar, dan kan slechts een van de pretendenten bedoeld zijn, en welke van beide bedoeld is, hangt dan af van de datering.

In de collectie in ons Instituut voor het Nabije Oosten zijn er heel wat oorkonden, die gedateerd zijn naar de naam van Nebukadnezar en één van diens 42 regeringsjaren. Van de groep van ongeveer 250 kleine oorkonden uit Babylon, die ik aan 't begin van dit opstel vermeldde, zijn het er niet minder dan 150, dus veel meer dan de helft. Het zijn meestal lijsten van de meest verschillende offerdieren of offergaven; de gehele groep behoort bij elkaar. Er is geen aanleiding ook maar bij één van de oudste van deze oorkonden aan een ander te denken dan aan de grote Nebukadnezar zelf. Bij dit soort onderzoekingen mist men een concordantie van persoonsnamen, die up to date zou zijn. Tallquist, Namenbuch, hoe verdienstelijk dan ook, is onvolledig en verouderd. Desondanks is de rangschikking over het algemeen mogelijk.

Het tweede probleem is zuiver historisch van aard. Waarom kiezen beide pretendenten de naam van Nebukadnezar? Deze was blijkens de gegevens bij Dubberstein begin oktober 562 overleden, dus juist veertig jaar voor het eerste optreden van Nidintu-Bël. Aan een cyklisch getal zal men niet willen denken, aan een Nebukadnezar redivivus in de zin van een herleving van de overledene nog veel minder. Dat zou niet in de lijn liggen van de Babylonische denkbeelden omtrent het leven na de dood, en trouwens (men denke aan de tweede David) ook niet van de Israelitisch-Joodse. We moeten veeleer denken aan het familieverband. Beiden noemen zich Nebukadnezar, de zoon van Nabunaid. $\mathrm{Nu}$ is het eigenaardig, hoe zowel bij de Chaldeeuwse dynastie als ook bij de Achaemenieden dezelfde namen zich bij grootvader en kleinzoon herhalen. De stamboom, die Olmstead voor Nabopolassar heeft geconstrueerd, is wellicht aan kritiek onderhevig, maar zoveel blijft waarschijnlijk, dat 
zijn vader Nebukadnezar heette en een zoon is geweest van Bēl-ibni, de getrouwe volgeling en correspondent van Assurbanipal als de stadhouder van het Zeeland. Dus droeg de grote Nebukadnezar de naam van zijn grootvader. Voort is waarschijnlijk-hoewel op grond van de Babylonische bronnen onbewijsbaar-dat Nabonaid (zelf, tenminste van moederszijde, uit Harrăn afkomstig) zijn recht op de troon verworven heeft door een huwelijk met een dochter van de grote Nebukadnezar. Dan zou hij dus een zwager geweest zijn van Neriglissar, een oom van Amēl-Marduk en ten slotte ook van Labăši-Marduk. Is dit juist, dan lag het voor de hand, dat hij zijn zoon, een der jongere prinsen, die na de vermoording van Belsazar aanspraak verkreeg op de troon, weer naar de grootvader ,vernoemde". Bij de Achaemenieden kunnen wij hetzelfde verschijnsel opmerken: daar heten grootvaders en kleinzoons twee keer Cyrus en Cambyses.

Maar dan doet zich de vraag voor: wat is met de jonge Nebukadnezar, de zoon van Nabunaid, gebeurd toen Cambyses nog bij het leven van zijn vader als onderkoning van Babylon en daarmede van geheel de zuidelijke helft van het imperium optrad? Heeft Cambyses hem laten vermoorden en zijn later achtereenvolgens twee pretendenten onder zijn naam opgetreden? Het bedenkelijke is, dat deze geschiedenis dan opvallend zou gelijken op die van de-eveneens in opdracht van Cambyses vermoorde-Bardija, de pseudo-Smerdis. Dit is het punt waar de historische kritiek zou moeten ingrijpen. De problemen rondom de zogenaamde "Lügenkönige" zijn ook in het boek van Fr. Wilh.König over „Der falsche Bardija” nog niet opgelost. Maar hierover te handelen kan hier mijn taak niet zijn.

$\mathrm{Nu}$ nog even een overzicht over de oorkonden, die met zekerheid aan een van de beide pretendenten kunnen worden toegeschreven. Van Nebukadnezar III =Nidintu-Bēl zijn er negen oorkonden-kwitanties -waarvan 6 uit Babylon, twee uit Borsippa, een uit Sippar. De omvang van zijn rijk was dus beperkt tot noordelijk Babylonië en hij noemt zich dan ook slechts „,koning van Babylon” zonder aanspraak op het gehele rijk. Gautāma-Bardija, de zogenaamde pseudo-Smerdis, werd blijkens de Behistun-inscriptie op 29 september 522 door Darius gedood. Reeds vier dagen later, 3 oktober, is de eerste oorkonde van Nebukadnezar III, die uit Sippar, geschreven de volgende oorkonden zijn van 6 oktober, 9 oktober, 26 oktober, 29 oktober, 11 november, 24 november en 8 december van hetzelfde jaar 522. Op 13 december werd Nebukadnezar III door Darius bij de Tigris en op 18 december bij Zazanna aan de Eufraat verslagen; bij het laatste treffen vond Nebukadnezar III de dood. Zoveel over de korte loopbaan van deze usurpator met de trotse naam Nebukadnezar. Blijkens de afbeelding op de Behistun-rots was hij reeds een man op leeftijd, hetgeen zijn bewering een zoon van Nabonaid te zijn inderdaad alleszins mogelijk doet lijken. Volgens $\$ 18-20$ van de Behistun-inscriptie heeft Darius hem niet zoals Araka en de meeste andere pretendenten in het openbaar laten terechtstellen. Hier- 
door werd optreden van Araka onder dezelfde naam vermoedelijk vergemakkelijkt.

Wat deze Araka, dus Nebukadnezar IV, betreft, zo staat diens opstand vermoedelijk in verband met die van de tweede pseudo-Smerdis, Wahjazdāta. Hij is volgens $\S 49$ van de Behistun-inscriptie een Armeniër, dus uit het land Chaldu, zoals ook de naam van zijn vader Chaldita en ook wel zijn volkstype en klederdracht op het reliëf aantonen. Bij hem doet zich iets eigenaardigs voor: in de oorkonden uit Babylon, Sippar en Borsippa (dus in Noord-Babylonië) noemt hij zich eenvoudig ,,koning van Babylon"; in een bepaalde groep van oorkonden uit Uruk en omstreken echter „koning van Babylon en der landen”, dus met aanspraak op beide helften van het imperium, ook van Irăn. De eerste oorkonde uit Uruk, met de uitgebreide titel, is van 25 augustus 521, de volgende van deze groep zijn van $2,4,9,10,13,15,20$ september, verder van 8,10 (niet minder dan drie oorkonden op één dag), 12, 13, 20, 31 oktober en van 3 november 521. De oorkonden uit Babylon zijn van 21 september en 3 oktober, die uit Borsippa van 22 september, uit Sippar van 1 oktober en 3 november. Men krijgt de indruk dat hij zich in Uruk bij de tempel van Isjtar heeft laten kronen: dat zou in dat jaar op 8 september gebeurd moeten zijn: op 1 Elul, de heilige maand van de godin Isjtar. Pas eind september is hij dan naar het noorden en naar de hoofdstad doorgedrongen, waar zijn positie vermoedelijk zwakker is geweest, zodat hij daar met de lagere titel tevreden was. In Sippar wordt nog op 8 september een oorkonde naar Darius gedateerd. Als het uitgangspunt van zijn samenzwering wordt in Behistun $§ 49$ de streek Dubbăla genoemd, die ik liefst in het zuiden, bij Uruk, zou willen zoeken. De plaats van zijn gevangenneming zou eveneens in het zuiden geweest kunnen zijn. Op 27 november, dus drie weken na de laatste oorkonde, die op zijn naam luidt, wordt hij overwonnen en wreed terechtgesteld.

Wat zijn hiervan de gevolgen geweest? Ten eerste, dat Darius de hoofdstad heeft doen ontmantelen. Herodotus heeft een halve eeuw later de muren van Babylon niet meer in hun oude glorie aanschouwd. Het gevolg is bij hem weer schromelijke overdrijving: hij spreekt van een lengte van ongeveer $95 \mathrm{~km}$. (Her. I, 185, e.v.): een bijna belachelijke overdrijving.

Het tweede gevolg is een nieuwe regeling der satrapieën. Uštāni wordt de nieuwe satraap over Babylon en Ebir-nări, d.i. het land ten westen van de Eufraat; Palestina wordt onder Tatnai een zelfstandig onderdeel van Ebir-nari, daar Uštāni in Babylon bleef resideren en dus een nadere verdeling in kleinere provincies wenselijk was. En nu heeft Darius niet alleen de reeds door Cyrus in 538 gegeven machtiging hernieuwd om de tempel in Jeruzalem te herbouwen, maar ook-en dit feitelijk voor het eerst_-een groot gedeelte van de Gōlā-de Joodse ballingen-naar hun land terug laten keren. Men zou zich kunnen afvragen: was deze maatregel bedoeld als een beloning voor trouwe diensten of als straf wegens afvalligheid en heulen met de pretendenten? De Joden 
waren sedert drie generaties in Babylonië ingeburgerd en uit tal van oorkonden blijkt hun voorspoed. Ik wil niet direct beweren dat een decreet tot terugkeer van een grotere groep van Joden een deportatie betekent, zij het dan nu in de omgekeerde richting-maar veel kan daaraan toch niet hebben gescheeld. In ieder geval stond deze maatregel in verband met de nieuwe organisatie en indeling van de provincies. Palestina als steunpunt van het rijk in de richting van Egypte, had versterking nodig, en nieuwe zelfstandigheid-ook op sacraal gebiedbinnen de grenzen van het imperium. Deze steun word aan het land geboden door de terugkeer van de ballingen onder Zerubbabel. $\mathrm{Nu}$ begint de definitieve herbouw van de tempel, zoals die door Haggai en Zacharia vermeld wordt. Dat deze tempel wellicht-zoals we gezien hebben-reeds dertig jaar later onder Xerxes weer verwoest werd, was tragisch. Maar verder kan $\mathrm{ik}$ op deze dingen hier niet ingaan.

F. M. Th. de Liagre Böhl, Oud-hoogleraar te Leiden. 